DOI 10.14746/ssp.2016.4.13

Beata PAJĄK-PATKOWSKA

Uniwersytet im. Adama Mickiewicza w Poznaniu

\title{
Kobiety jako uczestniczki sprawowania władzy w Polsce po 1989 r.
}

\begin{abstract}
Streszczenie: W oparciu o analizę dostępnych danych statystycznych prześledzone zostanie uczestnictwo kobiet w sprawowaniu władzy na szczeblu centralnym - zarówno ustawodawczej, jak i wykonawczej. Podjęta zostanie również próba wyjaśnienia dysproporcji pomiędzy kobietami i mężczyznami w sprawowaniu władzy i ewentualnych tego konsekwencji. Tak więc główne pytania badawcze zostały sformułowane w następujący sposób: Jaki jest udział kobiet w organach władzy ustawodawczej, czyli w Sejmie oraz w Senacie? Jaki jest udział kobiet w strukturach partii politycznych w Polsce? Ile kobiet pełni funkcje kierownicze w partiach politycznych? Jaki jest udział kobiet w organach władzy wykonawczej w Polsce? Na czele jakich resortów kobiety stają najczęściej? Z czego wynika różnica w poziomie uczestnictwa kobiet w organach władzy ustawodawczej i wykonawczej w Polsce? Jakie mogą być konsekwencje różnego uczestnictwa kobiet i mężczyzn w procesie sprawowania władzy?
\end{abstract}

Słowa kluczowe: kobiety w polityce, kobiety u władzy, III RP

\section{Władza polityczna - definicja}

Władza polityczna rozumiana będzie jako rządzenie, sprawowane za pośrednictwem organów stanowiących prawo oraz je realizujących. W oparciu o analizę dostępnych danych statystycznych prześledzone zostanie uczestnictwo kobiet w sprawowaniu władzy na szczeblu centralnym - zarówno ustawodawczej, jak i wykonawczej. Podjęta zostanie również próba wyjaśnienia dysproporcji pomiędzy kobietami i mężczyznami w sprawowaniu władzy i ewentualnych tego konsekwencji. Tak więc główne pytania badawcze zostały sformułowane w następujący sposób: Jaki jest udział kobiet w organach władzy ustawodawczej, czyli w Sejmie oraz w Senacie? Jaki jest udział kobiet w strukturach partii politycznych w Polsce? Ile kobiet pełni funkcje kierownicze w partiach politycznych? Jaki jest udział kobiet w organach władzy wykonawczej w Polsce? Na czele jakich resortów kobie- 
ty stają najczęściej? Z czego wynika różnica w poziomie uczestnictwa kobiet w organach władzy ustawodawczej i wykonawczej w Polsce? Jakie mogą być konsekwencje różnego uczestnictwa kobiet i mężczyzn w procesie sprawowania władzy?

\section{Kobiety jako uczestniczki procesu kreowania władzy - wybory, wladze partii}

W Polsce różnica w frekwencji wyborczej pomiędzy kobietami i mężczyznami utrzymuje się na poziomie ok. 5\% (por. Cześnik, 2007). Ogólny wskaźnik przynależności partyjnej w Polsce wynosi 4,2\% (Diagnoza społeczna 2015, dostęp dnia 20 IV 2016). Kobiety zrzeszają się o 20\% rzadziej niż mężczyźni, są również o $20 \%$ mniej aktywne w działaniach partii, co oznacza, że rzadziej np. zabierają głos podczas zebrań, a także rzadziej w nich uczestniczą (ibidem).

Co równie istotne, kobiety są słabiej reprezentowane we władzach partii. W żadnej z głównych sił politycznych nie znajdziemy kobiety w funkcji przewodniczącego. W Prawie i Sprawiedliwości (jedna na czterech wiceprzewodniczących - Beata Szydło), PO (dwie na pięć - Ewa Kopacz i Hanna Gronkiewicz-Waltz), PSL (jedna na pięć - Stefania Urszula Pasławska) oraz SLD (jedna na dziewięciu wiceprezesów - Karolina Pawliczak) są one także w mniejszości, jeśli chodzi o funkcje wiceprzewodniczących. Jedynie w Nowoczesnej wśród trzech wiceprzewodniczących są dwie kobiety - Joanna Schimdt oraz Katarzyna Lubnauer. Te właśnie różnice mogą mieć duże znaczenie w wyjaśnianiu dysproporcji w obecności kobiet $\mathrm{w}$ gremiach sprawujących władze tak w parlamencie, jak i w rządzie ${ }^{1}$. Słabsza aktywność kobiet w działaniach partii powoduje, że rzadziej są one zauważane i brane pod uwage przy wyborach władz partii, a później innych obsadzanych przez władze tychże partii instytucjach czy stanowiskach. W poprzednim okresie czasu poziom uczestnictwa kobiet we władzach partii politycznych był zbliżony. Przewodniczącą Partii Demokratycznej była przez pewien czas Brygida Kuźniak, a w latach 2004-2005 na czele Unii Pracy stała Izabela Jaruga-Nowacka. W 2009 r. kobiety stanowiły $25 \%$ wśród przewodniczących partii politycznych i 13\% wśród członków zarządu.

${ }^{1}$ Dane dostępne na stronach internetowych partii (stan na dzień 15 maja 2016 r.). 


\section{Kobiety jako uczestniczki władzy ustawodawczej}

Początkowo obecność kobiet w Sejmie i Senacie była zbliżona. W pierwszych wolnych wyborach do Senatu w 1989 r. dostało się do niego 8\% kobiet, zaś w wyborach do Sejmu w 1991 - 10\%. Taka minimalna różnica utrzymywała się także w kolejnych wyborach, zaś w $2001 \mathrm{r}$. doszło do jedynego w historii polskiego parlamentaryzmu przypadku, gdy do Senatu dostało się więcej kobiet niż do Sejmu (23\% w stosunku do $20 \%$ ). Kolejne dwa wyborcze lata to spadek wybranych do Senatu kobiet - do 12\% w 2005 r. i 9\% w 2007 i utrzymujące się na poziomie $20 \%$ uczestnictwo kobiet w Sejmie. Wprowadzenie ustawy kwotowej w wyborach do Sejmu przyczyniło się w 2011 r. do niewielkiego wzrostu wybranych tu kobiet (24\%) i 27\% w 2015. Niezmieniona ordynacja wyborcza do Senatu, a zwłaszcza niekorzystny dla kobiet system większościowy obowiązujący w tych wyborach, to prawdopodobne przyczyny utrzymywania się niewielkiej reprezentacji kobiet w tym organie $(13 \%$ w obu przypadkach).

Wykres 1. Udzial Kobiet w Sejmie i Senacie po 1989 r.

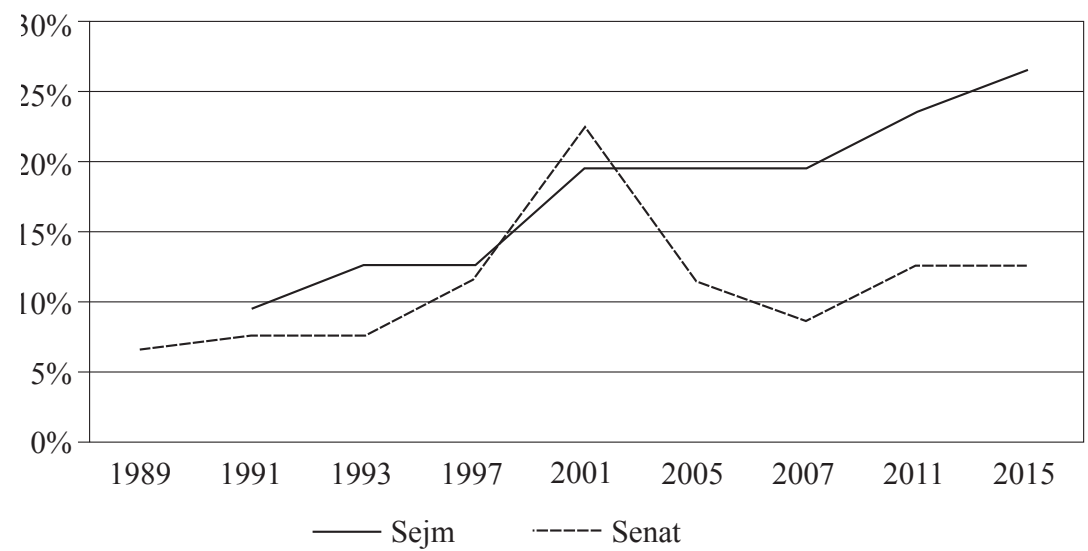

Źródło: Opracowanie własne.

\section{Kobiety w Sejmie i Senacie - liczba, funkcje}

Po 1989 r. kobiety niezwykle rzadko pełniły ważne funkcje w Sejmie i Senacie. Po raz pierwszy Marszałkiem Sejmu została kobieta 
w Sejmie VII kadencji. Najpierw funkcję tą pełniła Ewa Kopacz, a po tym, jak przejęła ona po Donaldzie Tusku stery rządu, zastąpiła ją Małgorzata Kidawa-Błońska. W przypadku Senatu jedyną kobietą pełniącą funkcję Marszałka była Alicja Grześkowiak (IV kadencja). Niewiele pań znalazło się również wśród wicemarszałków obu izb. W przypadku Sejmu były to: Olga Krzyżanowska (II), Genowefa Wiśniowska (V), Ewa Kierzkowska (VI), Wanda Nowicka i Elżbieta Radziszewska (VI) oraz Małgorzata Kidawa-Błońska i Barbara Dolniak w VIII kadencji. W sejmach I, III oraz IV kadencji nie było żadnej kobiet w tej funkcji. Z kolei w Senacie wicemarszałkiem były: dwukrotnie Zofia Kuratowska (I i III kadencja), Alicja Grześkowiak (II), Jolanta Danielak (V), Krystyna Bochenek i Grażyna Sztark (VII), Maria Pańczyk-Poździej (VIII), Maria Koc (IX).

Kobiety rzadko stają także na czele komisji sejmowych, przynależą zaś głównie do komisji zajmujących się stereotypowo kobiecymi sprawami, np. w 2011 r. stanowiły 53\% członków Komisji Polityki Społecznej i Rodziny, 42\% Edukacji, Nauki i Młodzieży, w porównaniu do 5\% Komisji, Kultury Fizycznej, Sportu i Turystyki czy 11\% członków Komisji Skarbu Państwa. Na 29 komisji kobiety stały na czele jedynie czterech z nich. To zróżnicowanie obszarów działań kobiet i mężczyzn w komisjach sejmowych, znajduje również potwierdzenie w wynikach badań parlamentarzystów i parlamentarzystek, przeprowadzonych w 2015 r. Kobiety zdecydowanie częściej deklarowały zainteresowanie edukacją, ochroną zdrowia, polityką społeczną i kulturą, natomiast mężczyźni - gospodarką, sprawami zagranicznymi i europejskimi (http://serwis.mamprawowiedziec. pl/2013/03/Kim-sa-kobiety-w-polskim-parlamencie.html).

\section{Kobiety jako uczestniczki wladzy wykonawczej - rząd}

W okresie pomiędzy 1989 a 2016 r. w Polsce mieliśmy siedemnaście rządów. W tym czasie funkcję premiera pełniły trzy kobiety. Były to Hanna Suchocka (11 lipca 1992-18 października 1993), Ewa Kopacz (22 września 2014-16 listopada 2015) i pełniąca obecnie tą funkcję Beata Szydło (od 16 listopada 2015). Czas sprawowania kobiecych rządów wyniósł 34 miesiące, czyli ok. 20\% całego tego czasu. W analizowanym okresie cztery razy panie sprawowały także funkcję wicepremiera - Izabela Jaruga-Nowacka dwukrotnie, jeden raz Zyta Gilowska, jeden raz Elżbieta Bieńkowska. 
Pierwszy okres po zmianie systemu charakteryzował się bardzo niską obecnością kobiet w strukturach władzy wykonawczej. Na siedem rządów tylko w pięciu zasiadały kobiety w randze ministrów, w dwóch, tzn. w rządzie Jana Olszewskiego oraz Hanny Suchockiej nie było ani jednej pani pełniącej funkcję ministra. Sytuacja uległa poprawie w okresie rządów Jerzego Buzka, gdzie na różnych jego etapach ministrami było pięć kobiet. Później sytuacja powróciła do tej z początków III RP, mimo że rządy w tym czasie należały do postulującego równość płci Sojuszu Lewicy Demokratycznej. I tak w rządzie Leszka Millera, w różnych jego okresach na czele ministerstw stały trzy kobiety, natomiast w dwóch kolejnych rządach Marka Belki była tylko jedna minister. Po raz kolejny sytuacja uległa nieznacznej poprawie w okresie rządów Kazimierza Marcinkiewicza, w którym mieliśmy od trzech do pięciu kobiet. Taka sama liczba pań znalazła się w rządzie Jarosława Kaczyńskiego. W okresie rządów sprawowanych przez PO i PSL pań było pomiędzy cztery a pięć. W obecnym rządzie, na czele którego stoi Beata Szydło, mamy cztery panie pełniące funkcje ministrów.

Interesujące informacje przynosi także analiza rodzaju ministerstw, na czele których w ostatnich 26 latach stawały panie. Najczęściej kobiety przewodziły resortom: edukacji narodowej, rodziny, pracy i opieki społecznej oraz infrastruktury i rozwoju regionalnego. Takich przypadków było po pięć w każdym obszarze. Trzykrotnie kobiety stawały na czele ministerstwa finansów, ministerstwa gospodarki przestrzennej, ministerstwa nauki i szkolnictwa wyższego oraz ministerstwa kultury. Dwukrotnie zaś przewodziły ministerstwom spraw zagranicznych, sprawiedliwości oraz sportu. Jak więc widać, panie wybierane były do zajmowania się głównie tymi sprawami, które stereotypowo zaliczane są do kobiecych specjalności. Ani razu nie zaproponowano im kierowania ministerstwem obrony narodowej, zaledwie raz przewodziły ministerstwu spraw wewnętrznych i administracji. Rozszerzone analizy polskiej elity rządowej z uwzględnieniem m.in. płci prowadziła także A. Kwiatkowska (2006). Oprócz ministrów w skład elity rządowej zaliczono także sekretarzy, podsekretarzy stanu oraz wojewodów. Kobiety stanowiły 14,2\% składu rządów J. Buzka i L. Millera. Nieco więcej było ich w rządzie Buzka (15,1\% w porównaniu do $13,2 \%$ ). Najwięcej było ich w ministerstwach gospodarki, pracy i polityki społecznej (28), zdrowia (26), nauki (25) oraz finansów (23). Najmniej zaś w ministerstwie infrastruktury (0), spraw wewnętrznych (0) i obrony narodowej (8). Tak więc wskazany wyżej wzór problematyki powierzanej kobietom, znalazł także tu potwierdzenie. Wykorzystywana w analizach prowadzonych przez Unię Europejską typologia ministerstw 
wyróżnia cztery ich typy: B (basic functions) - funkcje podstawowe (sprawy zagraniczne i wewnętrzne, obrony, sprawiedliwości), E - ekonomiczne (finanse, handel, przemysł, rolnictwo), I - infrastrukturalne (komunikacja, środowisko), S - społeczno-kulturalne (sprawy społeczne, zdrowie, rodzina, edukacja, nauka, kultura, praca, sport). Najwięcej kobiet zajmowała do tej pory stanowiska związane z funkcjami społecznokulturowymi oraz ekonomicznymi.

Informacje na temat czasu sprawowania funkcji oraz resortów (z uwzględnieniem typologii BEIS), których pracami kierowały kobiety, znajdują się w tabeli poniżej.

Tabela 1

Kobiety na czele ministerstw w latach 1989-2016

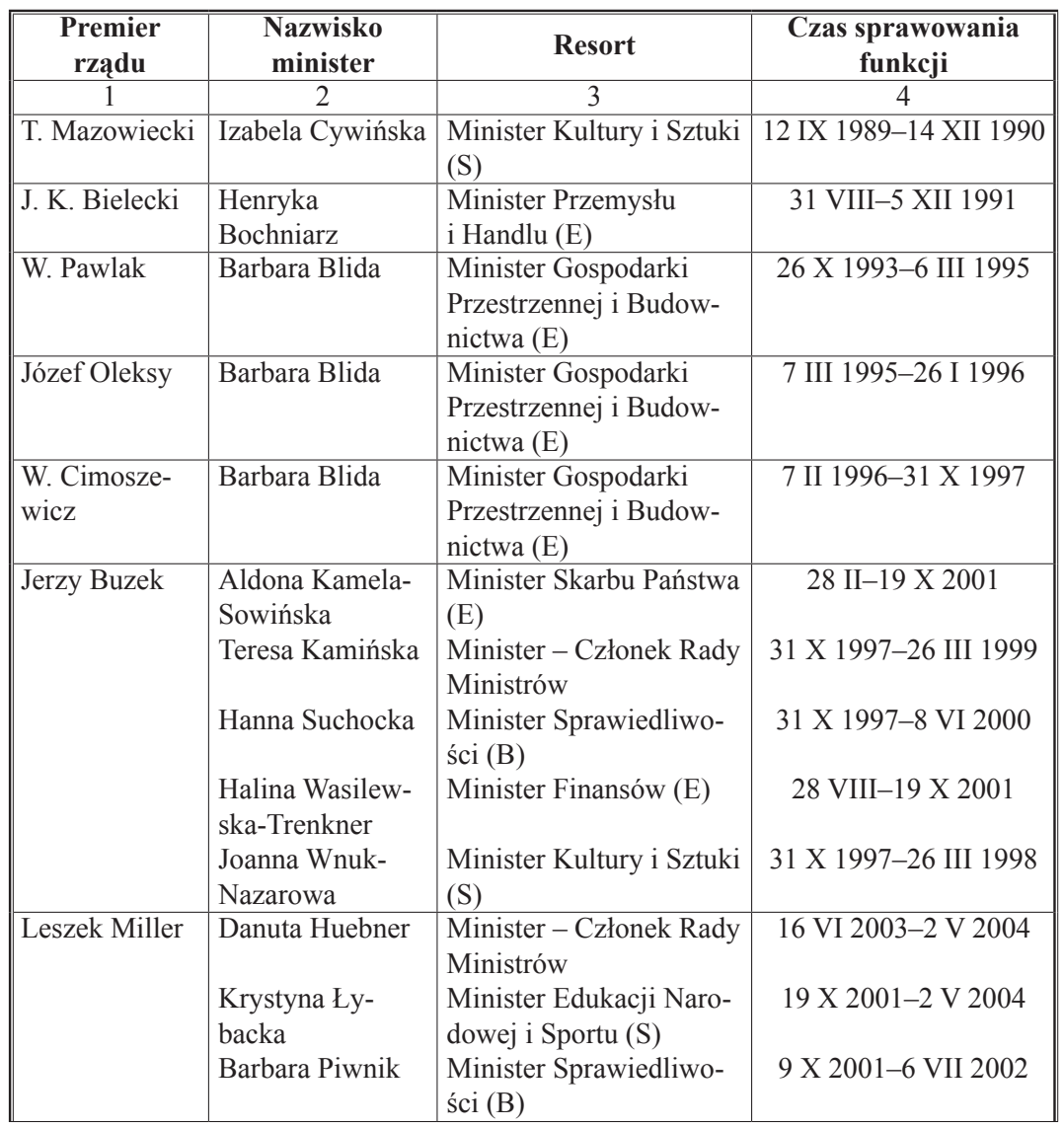




\begin{tabular}{|c|c|c|c|}
\hline 1 & 2 & 3 & 4 \\
\hline Marek Belka & $\begin{array}{l}\text { Izabela Jaruga- } \\
\text { Nowacka }\end{array}$ & $\begin{array}{l}\text { Minister Polityki Spo- } \\
\text { łecznej (S) }\end{array}$ & $2 \mathrm{~V} \mathrm{2004-31X2005}$ \\
\hline $\begin{array}{l}\text { Kazimierz } \\
\text { Marcinkiewicz }\end{array}$ & $\begin{array}{l}\text { Anna Fotyga } \\
\text { Grażyna Gęsicka } \\
\text { Zyta Gilowska } \\
\text { Anna Kalata } \\
\text { Teresa Lubińska }\end{array}$ & $\begin{array}{l}\text { Minister Spraw Zagra- } \\
\text { nicznych (B) } \\
\text { Minister Rozwoju Re- } \\
\text { gionalnego (I) } \\
\text { Minister Finansów (E) } \\
\text { Minister Pracy i Polityki } \\
\text { Społecznej (S) } \\
\text { Minister Finansów (E) }\end{array}$ & $\begin{array}{c}9 \text { V-14 VII } 2006 \\
31 \text { X 2005-14 VII } 2006 \\
7 \text { I 2006-24 VI } 2006 \\
5 \text { V-14 VII } 2006 \\
31 \text { X 2005-7 I } 2006\end{array}$ \\
\hline $\begin{array}{l}\text { Jarosław } \\
\text { Kaczyński }\end{array}$ & $\begin{array}{l}\text { Anna Fotyga } \\
\text { Grażyna Gęsicka } \\
\text { Zyta Gilowska } \\
\text { Elżbieta Jakubiak } \\
\text { Anna Kalata } \\
\text { Joanna Kluzik- } \\
\text { Rostkowska }\end{array}$ & $\begin{array}{l}\text { Minister Spraw Zagra- } \\
\text { nicznych (B) } \\
\text { Minister Rozwoju Re- } \\
\text { gionalnego (I) } \\
\text { Minister Finansów (E) } \\
\text { Minister Sportu i Tury- } \\
\text { styki (S) } \\
\text { Minister Pracy i Polityki } \\
\text { Społecznej (S) } \\
\text { Minister Pracy i Polityki } \\
\text { Społecznej (S) }\end{array}$ & $\begin{array}{c}14 \text { VII 2006-7 IX } 2007 \\
10 \text { IX 2007-16 XI } 2007 \\
14 \text { VII 2006-7IX } 2007 \\
11 \text { IX 2007-16 XI } 2007 \\
22 \text { IX 2006-7 IX } 2007 \\
11 \text { IX 2007-16 XI } 2007 \\
23 \text { VII 2007-16 XI } 2007 \\
14 \text { VII 2006-13 VIII } 2007 \\
13 \text { VIII-16 XI } 2007\end{array}$ \\
\hline $\begin{array}{l}\text { Donald Tusk } \\
\text { (I rząd) }\end{array}$ & $\begin{array}{l}\text { Elżbieta Bień- } \\
\text { kowska } \\
\text { Jolanta Fedak } \\
\text { Katarzyna Hall } \\
\text { Ewa Kopacz } \\
\text { Barbara Ku- } \\
\text { drycka }\end{array}$ & $\begin{array}{l}\text { Minister Rozwoju Re- } \\
\text { gionalnego (I) } \\
\text { Minister Pracy i Polityki } \\
\text { Społecznej (S) } \\
\text { Minister Edukacji Naro- } \\
\text { dowej (S) } \\
\text { Minister Zdrowia (S) } \\
\text { Minister Nauki i Szkol- } \\
\text { nictwa Wyższego (S) }\end{array}$ & $\begin{array}{l}16 \text { XI } 2007 \\
16 \text { XI } 2007 \\
16 \text { XI } 2007\end{array}$ \\
\hline $\begin{array}{l}\text { Donald Tusk } \\
\text { (II rząd) }\end{array}$ & $\begin{array}{l}\begin{array}{l}\text { Barbara Ku- } \\
\text { drycka }\end{array} \\
\text { Joanna Mucha } \\
\text { Krystyna Szu- } \\
\text { milas } \\
\text { Elżbieta Bień- } \\
\text { kowska } \\
\text { Joanna Kluzik- } \\
\text { Rostkowska } \\
\text { Lena Kolarska- } \\
\text { Bobińska } \\
\text { Małgorzata Omi- } \\
\text { lanowska }\end{array}$ & $\begin{array}{l}\text { Minister Nauki i Szkol- } \\
\text { nictwa Wyższego (S) } \\
\text { Minister Sportu i Tury- } \\
\text { styki (S) } \\
\text { Minister Edukacji Naro- } \\
\text { dowej (S) } \\
\text { Minister Infrastruktury } \\
\text { i Rozwoju Regionalne- } \\
\text { go (I) } \\
\text { Minister Edukacji Naro- } \\
\text { dowej (S) } \\
\text { Minister Nauki i Szkol- } \\
\text { nictwa Wyższego (S) } \\
\text { Minister Kultury i Dzie- } \\
\text { dzictwa Narodowego (S) }\end{array}$ & $\begin{array}{l}18 \text { XI 2011-27 XI } 2013 \\
18 \text { XI 2011-27 XI } 2013 \\
18 \text { XI 2011-27 XI } 2013 \\
27 \text { XI } 2013 \\
27 \text { XI } 2013 \\
3 \text { XII } 2013 \\
17 \text { VI } 2014\end{array}$ \\
\hline
\end{tabular}




\begin{tabular}{|c|c|c|c|}
\hline 1 & 2 & 3 & 4 \\
\hline Ewa Kopacz & $\begin{array}{l}\text { Joanna Kluzik- } \\
\text { Rostkowska } \\
\text { Lena Kolarska- } \\
\text { Bobińska } \\
\text { Małgorzata Omi- } \\
\text { lanowska } \\
\text { Teresa Piotrow- } \\
\text { ska } \\
\text { Maria Wasiak }\end{array}$ & $\begin{array}{l}\text { Minister Edukacji Naro- } \\
\text { dowej (S) } \\
\text { Minister Nauki i Szkol- } \\
\text { nictwa Wyższego (S) } \\
\text { Minister Kultury i Dzie- } \\
\text { dzictwa Narodowego (S) } \\
\text { Minister spraw we- } \\
\text { wnętrznych (B) } \\
\text { Minister Infrastruktury } \\
\text { i Rozwoju Regionalnego } \\
\text { (I) }\end{array}$ & 22 IX 2014 \\
\hline Beata Szydło & $\begin{array}{l}\text { Beata Kempa } \\
\text { Elżbieta Rafalska } \\
\text { Anna Streżyńska } \\
\text { Elżbieta Witek } \\
\text { Anna Zalewska }\end{array}$ & $\begin{array}{l}\text { Minister - Członek Rzą- } \\
\text { du } \\
\text { Minister Rodziny, Pracy } \\
\text { i Polityki Społecznej (S) } \\
\text { Minister Cyfryzacji (I) } \\
\text { Minister - Członek Rzą- } \\
\text { du } \\
\text { Minister Edukacji Naro- } \\
\text { dowej (S) }\end{array}$ & 16 listopada $2015 \mathrm{r}$. \\
\hline
\end{tabular}

Źródło: Opracowanie własne.

Analizy prowadzone przez M. Musiał-Karg w 2008 r. (Musiał-Karg, 2008) oraz przez M. Musiał-Karg i E. Lesiewicz (Musiał-Karg, Lesiewicz, 2016) w 2015 r. wykazały, iż w krajach Europy Zachodniej kobiety stanowią ok. 1/3 składu rządu. Można powiedzieć, że po 27 latach, jakie upłynęły od zmiany systemowej, zaczynamy zbliżać się do tego poziomu, choć wciąż występują duże wahania w poziomie uczestnictwa kobiet w składach poszczególnych rządów.

\section{Przyczyny obserwowanych różnic}

Część przyczyn mniejszej obecności kobiet w różnych gremiach sprawujących władzę polityczną wynika z mniejszej reprezentacji oraz mniejszej aktywności kobiet w organizacjach kreujących te gremia. Analizy prowadzone przez J. Raciborskiego wykazały, że dominującym typem drogi do elity rządowej (w rządach J. Buzka oraz L. Millera) była droga partyjna - 48\% przypadków. Druga w kolejności droga naukowo-ekspercka stanowiła 23\% przypadków w badanym okresie. Mniejsza obecność kobiet w parlamencie, w rządach czy w związkach zawodowych 
obniża również szansę wejścia do elit jedną z pozostałych wyróżnionych przez J. Raciborskiego dróg. Tak więc wykazana w Diagnozie społecznej o $20 \%$ niższa obecność oraz niższa aktywność kobiet w partiach politycznych, ma swoje dalsze poważne konsekwencje. W momencie decydowania o tym, kto ma się znaleźć na listach wyborczych, a później kto ma pełnić ważne funkcje czy to w Sejmie, czy w rządzie, kobiety są rzadziej uwzględniane (zob. również Nalewajko, 2011). Zauważmy, że $20 \%$ wyjściowa różnica w aktywności partyjnej kobiet, przekłada się na wielokrotnie niższą obecność kobiet np. w rządzie. Krytykowane często rozwiązania prawne w postaci systemów kwotowych przy tworzeniu partyjnych list wyborczych, mogłyby częściowo rozwiązać ten problem. Zastanawiać się można, czy podobne rozwiązania nie powinny również objąć np. obsadzania stanowisk w gremiach decyzyjnych.

Jednak prawdopodobnie ważniejsze byłoby wyjaśnienie powstania wyjściowej różnicy w poziomie uczestnictwa kobiet w partiach politycznych. Z czego wynika owa 20\% luka? Czy z mniejszego zainteresowania kobiet aktywnością w tej sferze, czy z obaw przed wkraczaniem do stereotypowo postrzeganego jako arena męskiej aktywności, świata? Dotychczas prowadzone badania potwierdzają przynajmniej częściowo, te przypuszczenia.

I tak, badania dotyczące postrzegania zawodu polityka oraz kobiety i mężczyzny wykazały po pierwsze, że stereotyp zawodu polityka jest bardziej zbliżony do stereotypowo przypisywanych mężczyznom cech. Po drugie zaś, oba stereotypy okazały się odporne na zmiany. Co ciekawe badania te prowadzone były wśród studentek i studentów m.in. kierunków politycznych, a więc grupy bardziej pod tym względem uświadomionej (Pająk, 2005; Pająk-Patkowska, 2010).

\section{Konsekwencje obserwowanych różnic}

Część naukowców, zwłaszcza mężczyzn, poddaje w wątpliwość sens analiz dotyczących różnic związanych z płcią, zwłaszcza tych w obszarze władzy politycznej. Czy jest ważne, aby kobiety i mężczyźni na równi, lub chociaż w zbliżonej proporcji, uczestniczyli w sprawowaniu władzy? Czy polityka kreowana przy większym udziale kobiet byłaby lepsza?

Na tak sformułowane wątpliwości, można spróbować odpowiedzieć, wskazując kilka co najmniej argumentów.

Po pierwsze, mniejszy udział kobiet we władzy przekłada się na mniejsze możliwości kreowania przez nie kształtu polityki państwa. Kobiety, 
ze względu na nieco inne doświadczenia, związane chociażby z opieką nad dziećmi, mogą wnieść do polityki nowe, niedostrzegane przez mężczyzn perspektywy. Badania prowadzone nad różnicami w funkcjonowaniu poznawczym i emocjonalnym kobiet i mężczyzn wskazują również, że zróżnicowanie płciowe grup podejmujących decyzje, może przyczynić się do wzrostu efektywności i podniesienia jakości podjętych decyzji (por. Pająk-Patkowska, 2016).

Po drugie, mniejszy udział we władzy to także mniejsza obecność w mediach, a w konsekwencji sprawy ważne dla kobiet oraz ich perspektywa są mniej obecne w dyskursie politycznym² ${ }^{2}$. Często o sprawach ściśle związanych z kobietami - ich bezpieczeństwem i prawami, dyskutują, a potem podejmują decyzje mężczyźni. Prawdopodobnie, odwrócenie tej sytuacji i decydowanie o sprawach mężczyzn przez kobiety, wywołałoby dużo większy opór, niż ten, który stawiają obecnie kobiety.

Mniejsza obecność w mediach oraz pokazywanie kobiet tylko w kontekście spraw stereotypowo kobiecych, może przyczyniać się również do utrwalenia stereotypów płci. Te zaś mają kluczowe znaczenie dla wyjaśnienia tak mocnego podziału na zawody męskie i kobiece. Większe zainteresowania techniką i naukami ścisłymi wynika bowiem nie z biologicznie zdeterminowanej większej zdolności mężczyzn w tych obszarach. To otoczenie, w postaci rodziców, nauczycieli czy mediów w dużej mierze kreuje to zróżnicowanie. Często dziewczynki czy kobiety, które wykazują zainteresowania męskimi zajęciami są traktowane bądź jako wyjątki potwierdzające regułę, bądź jako egzemplarze naruszające naturalny porządek rzeczy. Podobnie rzecz ma się także z mężczyznami, którzy zainteresowani są zajęciami przypisanymi w stereotypie kobietom. Tak więc w sytuacji, gdy polityka wciąż postrzegana jest jako sfera męskiej aktywności, kobiety z jednej strony będą odczuwały większy opór przed zaangażowaniem się $\mathrm{w}$ nią, $\mathrm{z}$ drugiej będą miały większe trudności w wejściu w tą sferę i odniesienie w niej sukcesu (Pająk, 2006; PająkPatkowska, 2011).

\section{Bibliografia}

Cześnik M. (2007), Partycypacja wyborcza w Polsce, Wydaw. ISP PAN, Scholar, Warszawa.

2 Szerzej na ten temat zob. A. Philips, 2003. 
Database on Women and Men in Decission-making - Europa (2010), www.ec.europa. eu/social/BlobServlet?docId=4481\&langId=en, 15 V 2016.

Diagnoza społeczna, raporty (2015), red. J. Czapiński, T. Panek, www.diagnoza.com, $15 \mathrm{~V} 2016$.

Fuszara M. (2006), Kobiety w polityce, Trio, Warszawa.

Kamola-Cieślik M. (2009), Działalność kobiet $w$ Radzie Ministrów $w$ latach 1989-2008, w: Kobiety we współczesnej Europie, red. M. Musiał-Karg, Wydawnictwo A. Marszałek, Toruń.

Koźbiał K. (2016), Women's participation in political bodies at the central level in the Viegrad Group countries, w: Women's role and their participation in the public life of the Visegrad Countries, red. M. Musiał-Karg, E. Lesiewicz, Wydawnictwo Naukowe WNPiD UAM, Poznań-Usti nad Labem.

Kwiatkowska A. (2006), Charakterystyka społeczno-demograficzna polskiej elity rzadowej 1997-2004, w: Elity rzqdowe III RP. Portret socjologiczny, red. J. Raciborski, Trio, Warszawa.

Musiał-Karg M. (2009), Kobiety w organach władzy ustawodawczej i wykonawczej, w: Kobiety we współczesnej Polsce, red. M. Musiał-Karg, Wydawnictwo A. Marszałek, Toruń.

Musiał-Karg M., Lesiewicz E. (2016), Women's prticipation inlegislative and executive institutions in the European Union and in Visegrad Group countries, w: Women's role and their participation in the public life of theViserad Countries, red. M. Musiał-Karg, E. Lesiewicz, Wydawnictwo Naukowe WNPiD UAM, Poznań-Usti nad Labem.

Nalewajko E. (2010), Partyjne bariery awansu kobiet $w$ polityce, w: Kobiety $u$ wta$d z y$, red. I. Pańków, B. Post, ISP PAN, Warszawa.

Norris P., Inglehart R. (2002), Cultural Barriers to Women's Leadership: A Worldwide Comparison.

Pająk B. (2006), Płeć a kariera polityczna, „Przegląd Politologiczny”, nr 4.

Pająk-Patkowska (2011), Psychologiczne uwarunkowania aktywności politycznej kobiet, ,Przegląd Politologiczny”, nr 2.

Pająk-Patkowska B. (2012), Stereotyp kobiety i polityka - stagnacja czy ewolucja, w: A. Balczyńska-Kosman, I. Andruszkiewicz, J. Kałużna, E. Kania, Gender jako determinanta w przestrzeni prywatnej i publicznej, Wydaw. WNPiD UAM, Poznań.

Pająk-Patkowska B. (2016), Kobieta jako podmiot i przedmiot wpływu społecznego, w: Wplyw spoleczny - konteksty i zastosowania badawcze, red. B. Pająk-Patkowska, Wydaw. WNPiD UAM, Poznań.

Philips A. (2003), Przestrzeń publiczna, życie prywatne, w: Aktorzy Życia publicznego. Pteć jako czynnik różnicujacy, red. R. Siemieńska, Wydaw. Naukowe Scholar, Warszawa.

Raciborski J. (2006), Konstruowanie rzqdów i elit rzqdowych, w: Elity rzqdowe III RP. Portret socjologiczny, red. J. Raciborski, Trio, Warszawa. 


\section{Women as participants of government in Poland after 1989}

\section{Summary}

Basing on the analysis of available statistical data, this article presents Polish women's participation in the processes of exercising political power (legislative and executive) within central institutions of the state. The analysis covered a time frame between 1989 and 2015. The reasons for disparities between the numbers of women and men in political authorities as well as its possible consequences have also been illustrated. The received results allow arriving at the following conclusions. In the analysed period, a considerable increase in the number of women in both chambers of the Polish parliament and the subsequent governments was observed. However, the numbers are still far from political parity. In case of the government, the increased presence of women holding posts of the heads of ministries for affairs traditionally linked with feminine activity (e.g. culture, education, social policy) can also be underlined. Inequality within the area of exercising political authority may exert a significant impact on the society, i.e. limit the ability to shape the state policy within areas particularly interesting to women or reinforce gender stereotypes in the society.

Key words: women in politics, women in power, the Third Polish Republic 